\title{
UPAYA PENINGKATAN HASIL BELAJAR TEMATIK MELALUI PENDEKATAN SCIENTIFIC \& MODEL THINK PAIR SHARE KELAS IV SD
}

\author{
Khamalatur Rizqi Meifani, Naniek Sulistya Wardani \\ Surel: krizqim@gmail.com
}

\begin{abstract}
The purpose of this study is to improve learning outcomes through the scientific approach and think pair models share 4th grade elementary school students. The research subjects of the fourth grade students at SDN Blotongan 01 were 19 students. Data collection techniques used are test and non-test (observation). The results of this study indicate that there is an increase in learning outcomes which is attempted through the scientific approach with proven think pair share models. This is indicated by the comparison of learning outcomes completeness cycle I: cycle II is 63\%: 95\%. Comparison of learning outcomes based on the average cycle I: cycle II is 75: 83. Comparison of the maximum score of cycle I: cycle II is 90: 100. Comparison of minimum scores of cycle I: cycle II is 50:64.
\end{abstract}

Keywords: Learning outcomes, Scientific, Think Pair Share

\begin{abstract}
ABSTRAK
Tujuan penelitian ini untuk meningkatkan hasil belajar melalui pendekatan scientific dan model think pair share siswa kelas IV SD. Subjek penelitian siswa kelas IV di SDN Blotongan 01 sebanyak 19 siswa. Teknik pengumpulan data yang digunakan yaitu tes dan non tes (observasi). Hasil penelitian ini menunjukkan terdapat peningkatan hasil belajar yang diupayakan melalui pendekatan scientific dengan model think pair share terbukti. Hal ini ditunjukkan berdasarkan perbandingan hasil belajar ketuntasan siklus I : siklus II adalah 63\% : 95\%. Perbandingan hasil belajar berdasarkan rata-rata siklus I : siklus II adalah $75: 83$. Perbandingan skor maksimal siklus I : siklus II adalah 90 : 100. Perbandingan skor minimal siklus I : siklus II adalah $50: 64$.
\end{abstract}

Kata Kunci: Hasil belajar, Scientific, Think Pair Share

PENDAHULUAN

Pendidikan

digalangkan

mengutamakan untuk meningkatkan

tidak hanya prestasi belajar saja melainkan juga kompetensi yang yang sedang dimiliki oleh siswa. Salah satu caranya di Indonesia dengan menerapkan pembelajaran tematik. Pembelajaran tematik adalah salah satu pendekatan dalam
Guru SDN Botani Salatiga
Accepted: 3 Desember 2018

Published: 18 Desember 2018 
pembelajaran terpadu (integrated instruction) yang merupakan suatu sistem pembelajaran yang memungkinkan peserta didik, baik secara individual maupun kelompok, aktif menggali dan menemukan konsep serta prinsip-prinsip keilmuan secara holistik, bermakna, dan autentik (Rusman: 2017: 357).

Setiap guru harus mengenal beberapa karakteristik kurikulum tematik yaitu seperti pembelajaran berpusat pada peserta didik, memberikan pengalaman langsung, menggunakan prinsip belajar sambil bermain, dan menyenangkan (Hajar: 2013: 43-55).

Berdasarkan hasil observasi kelas IV SDN Blotongan 01, nampak nilai rata-rata hasil belajar mencapai 62 yang berada di bawah KKM yang ditetapkan yaitu 75. Sementara itu dari ketuntasan nilai individu berdasarkan KKM diperoleh hasil bahwa dari 19 siswa hanya 8 siswa (42\%) siswa memenuhi KKM, sedangkan 11 siswa $(58 \%)$ belum tuntas atau belum mencapai KKM. Untuk skor maksimum mencapai 75 dan skor minimumnya 40 .

Penghitungan hasil belajar seharusnya dilakukan dari sekurangkurang aspek pengetahuan dan keterampilan. Seperti yang disebutkan dalam Permendikbud No 23 tentang penilaian pasal 3 menjelaskan bahwa penilaian hasil belajar peserta didik pada pendidikan dasar dan pendidikan menengah meliputi aspek sikap, pengetahuan, dan keterampilan. Dalam pasal 9 menyebutkan penilaian aspek pengetahuan dilakukan melalui tes tertulis, tes lisan dan penugasan sesuai dengan kompetensi yang dinilai, sedangkan penilaian keterampilan dilakukan melalui praktik, produk, proyek, portofolio, dan / atau teknik lain sesuai dengan kompetensi yang dinilai. Namun di SD, hasil belajar belum mengukur tentang aspek keterampilan yang dimiliki siswa.

Pelaksanaan pembelajaran di SD belum menuntut siswa untuk berpikir secara ilmiah. Siswa hanya menerima informasi tanpa mencoba pengalaman secara langsung. Hal ini bertentangan dengan pendekatan scientific. Pembelajaran berpendekatan scientific merupakan pembelajaran yang menggunakan pendekatan ilmiah dan inkuiri, dimana siswa berperan secara langsung baik secara individu maupun kelompok untuk menggali konsep dan prinsip selama kegiatan pembelajaran, sedangkan tugas guru adalah mengarahkan proses belajar yang dilakukan siswa dan memberikan koreksi terhadap konsep dan prinsip yang didapatkan siswa (Nurul dalam Marjan: 2014).

Tujuan dalam penelitian ini adalah untuk mengetahui apakah peningkatan hasil belajar tematik dapat diupayakan melalui pendekatan scientific dan model think pair share (TPS) di kelas VI SD dan bagaimana langkah-langkah pendekatan scientifik dan model think pair share dapat 
meningkatkan hasil belajar siswa kelas IV SD.

Permasalahan mengenai rendahnya hasil belajar, guru harus dapat menciptakan suasana pembelajaran yang dapat melibatkan siswa secara aktif dalam proses pembelajaran. Siswa terlibat langsung dalam pembelajaran sedangkan guru hanya sebagai fasilitator. Jadi hasil belajar merupakan pencapaian siswa melalui proses berpikir ilmiah dalam memperoleh pengetahuan dan keterampilan sehingga terjadi perubahan pada diri mereka masingmasing yang meliputi aspek kognitif, afektif, dan psikomotorik.

$\begin{array}{cc}\text { Langkah-langkah } & \text { pembelajaran } \\ \text { yang digunakan } & \text { berdasarkan }\end{array}$ pendekatan scientific dengan model think pair share yaitu 1) menyajikan informasi, 2) think, 3) pair, 4) share, 5) evaluasi, dan 6) penghargaan.

Hipotesis tindakan dalam penelitian ini adalah peningkatan hasil belajar diduga dapat diupayakan melalui pendekatan scientific dengan model think pair share siswa kelas IV SD dan melalui langkah-langkah pendekatan scientific dengan model think pair share diduga dapat meningkatkan hasil belajar siswa kelas IV SD.

\section{METODE PENELITIAN}

Jenis penelitian adalah Penelitian Tindakan Kelas (PTK) atau Classroom Action Research (SAR). Penelitian dilakukan pada semester II tahun pelajaran 2017/2018 di SDN Blotongan 01, Salatiga Jawa Tengah.
Subjek penelitian adalah siswa kelas IV SDN Blotongan 01, yang terdiri dari 19 siswa dengan jumlah siswa laki-laki 11 orang dan siswa perempuan berjumlah 8 orang.

Model PTK yang digunakan dari S. Kemmis \& Mc. Taggart yang perangkatnya terdiri atas tiga komponen, yaitu plan, act \& observe, dan reflect.

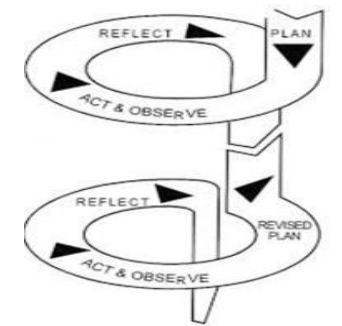

Gambar 1. Model Spiral PTK Kemmis dan Taggart

\section{Langkah 1: Perencanaan (Plan)}

Langkah-langkahnya adalah mempersiapkan rencana pembelajaran dengan model Think Pair Share (TPS), mempersiapkan lembar kerja yang akan diberikan kepada siswa pada setiap siklus, mempersiapkan penilaian tes yang berupa butir soal evaluasi, dan kemudian lembar penilaian non tes yang berupa rubrik penilaian keterampilan untuk setiap siklusnya.

\section{Langkah 2: Tindakan (Act) \& Pengamatan (Observe)}

Langkah diterapkan untuk siswa, sumber belajar, dan sistem evaluasi menggunakan model think pair share. Siswa dibagi menjadi heterogen kelompok yang terdiri dari 4-6 siswa agar setiap kelompok bisa berpasangan dibuat satu kelompok berisi genap 
anggota. Langkah selanjutnya adalah menerapkan think pair share melalui langkah-langkah sebagai berikut ini: langkah ke-1 adalah Menyajikan Informasi. Siswa diberikan informasi mengenai materi berupa teks bacaan yang akan digunakan dalam pembelajaran. Langkah ke-2 adalah Think. Siswa diminta untuk mengidentifikasi teks bacaan dalam lembar kerja. Langkah ke-3 adalah Pair. Setelah diidentifikasi siswa mendiskusikan hasil jawaban antar anggota kelompok dan memilih jawaban yang paling benar. Langkah ke-4 adalah Share. Hasil jawaban yang sudah disepakati dipresentasikan di depan kelas. Kelompok lain menyimak hasil jawaban dari kelompok yang mempresentasikan. Langkah ke-5 adalah Evaluasi. Kelompok yang tidak maju mengevaluasi hasil jawaban kelompok yang sedang mempresentasikan. Langkah ke-6 adalah Penghargaan. Kelompok yang menjawab dengan benar mendapat penghargaan, berupa pujian atau stiker bintang untuk menambah motivasi dan semangat siswa.

Mengamati aktivitas siswaselama pembelajaran. Tindakan siswa saat diskusi kelompok, hasil pengerjaan tugas, mempresentasikan hasil diskusi, dan tanggapan siswa kepada kelompok yang mempresentasikan.

\section{Langkah 3: Refleksi (Reflect)}

Refleksi mengacu pada pemikiran tentang hambatan yang pencapaian rendah dalam fase observasi. Hasil observasi dianalisis untuk mengetahui kelemahan pembelajaran untuk memperbaikinya.

Teknik pengumpulan data yang digunakan yaitu tes dan non tes (observasi). Alat pengumpulan data digunakan dalam pelaksanaan penelitian tindakan kelas yaitu lembar observasi, butir soal tes, dan rubirk non tes. Teknik analisis data dalam penelitian ini berupa deskriptif komparatif dengan membandingkan persentase ketuntasan kebermaknaan dan hasil belajar dengan pada siklus 1 dan 2.

\section{HASIL DAN PEMBAHASAN}

Hasil analisis belajar siswa sebelum dilakukan penelitian dengan melihat ketuntasan siswa didapat data dari pra siklus, siklus I, dan siklus II. Adapun hasil pra siklus, siklus I dan siklus II sebagai berikut:

\begin{tabular}{ccccccccc}
$\begin{array}{c}\text { N } \\
\text { o. }\end{array}$ & $\begin{array}{c}\text { Sko } \\
\text { r Kriteria }\end{array}$ & \multicolumn{2}{c}{$\begin{array}{c}\text { Pra } \\
\text { Siklus }\end{array}$} & Siklus I & \multicolumn{2}{c}{$\begin{array}{c}\text { Siklus } \\
\text { II }\end{array}$} \\
\hline 1 & & & $\mathrm{f}_{\mathrm{i}}$ & $\%$ & $\mathrm{f}_{\mathrm{i}}$ & $\%$ & $\mathrm{f}_{\mathrm{i} .}$ & $\%$ \\
\hline 2 & $<75$ & Tuntas & 8 & 42 & 12 & 63 & 19 & 100 \\
& & $\begin{array}{l}\text { Tidak } \\
\text { Tuntas }\end{array}$ & 11 & 58 & 7 & 37 & 0 & 0 \\
& & & & & & & \\
\hline
\end{tabular}

$\begin{array}{lllllll}\text { Jumlah } & 19 & 100 & 19 & 100 & 19 & 100\end{array}$

Tabel 1. Distribusi Frekuensi Hasil Belajar Siswa berdasarkan Ketuntasan Pra Siklus, Siklus I, \& Siklus II

Dari tabel 1 di atas, didapatkan pada saat awal sebelum dilakukan tindakan jumlah siswa yang tuntas ada 8 siswa belum mencapai $75 \%$ dari jumlah keseluruhan kelas. Siswa pasif 
dalam pembelajaran. Proses Dari analisis data di atas pembeajaran didominasi guru. didapatkan perbandingan ketuntasan Sehingga siswa tidak bisa mencoba, dari pra siklus, siklus I, siklus II sebesar menalar dan mengkomunikasikan 8 siswa: 12 siswa: 19 siswa. Dari hasil secara mandiri terkait pembelajaran yang disajikan dalam tabel 1 di atas, yang berlangsung. Pada siklus I sudah berikut gambar grafik perbandingan terjadi peningkatan namun siswa yang hasil belajar berdasarkan ketuntasan pra tuntas sejumlah 12 siswa juga belum siklus, siklus I dan siklus II sebagai mencapai $75 \%$ dari jumlah siswa berikut:

keseluruhan. Siswa mulai dilibatkan dalam proses pembelajaran. Sehingga siswa lebih mendalam dalam mengenal materi yang disampaikan guru. Hal ini membuat peningkatan pada hasil belajar siswa. Siswa yang tuntas sejumlah 12 siswa namun belum mencapai $75 \%$ dari jumlah keseluruhan siswa. Setelah dilakukan refleksi ternyata ada beberapa siswa yang belum maksimal terlibat dalam proses pembelajaran. Dalam tahap berbagi (think) siswa belum menggali informasi secara mendalam terhadap materi yang diberikan. Sehingga pada siklus II dilakukan perbaikan yaitu pada saat tahap bertukar pikir (pair) siswa dalam kelompok yang memiliki intelegensi di atas teman anggota kelompok yang lain diminta untuk menjadi tutor sebaya untuk membantu temannya yang masih kesulitan dalam mencari informasi atau materi yang dibutuhkan dalam diskusi kelompok. Setelah dilakukan perbaikan dalam siklus II, didapatkan hasil belajar siswa berdasarkan ketuntasan terjadi peningkatan lagi, jumlah siswa yang tuntas ada 19 siswa dan sudah melampaui $75 \%$ dari jumlah siswa keseluruhan.

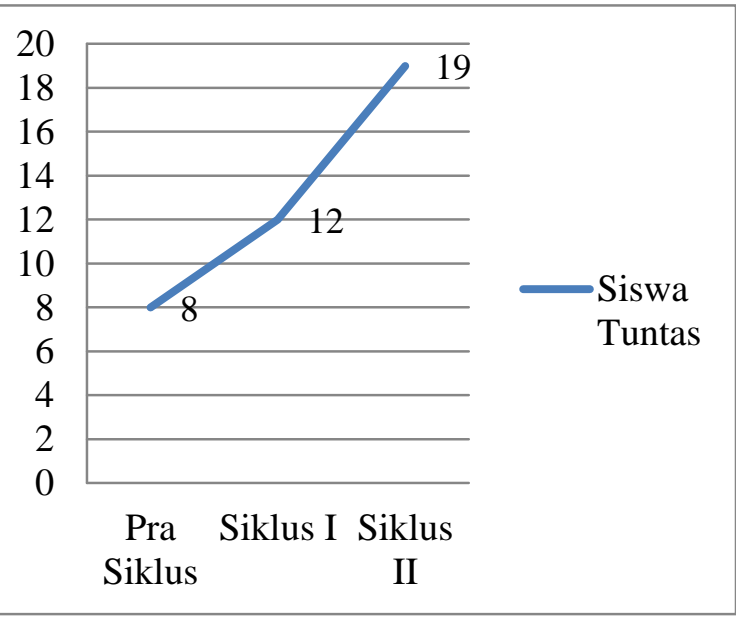

Gambar 2. Grafik Perbandingan Hasil Belajar Berdasarkan Ketuntasan pada Pra Siklus, Siklus I dan Siklus II

Berdasarkan gambar 2, nampak bahwa hasil belajar siswa berdasarkan ketuntasan siswa pada kegiatan pra siklus hanya mencapai $42 \%$ dari seluruh siswa. Pada siklus I siswa yang mencapai ketuntasan belajar 63\% dari seluruh siswa. Dan selanjutnya pada akhir siklus II siswa yang mencapai ketuntasan belajar meningkat menjadi $100 \%$ dari seluruh siswa.

Dilihat dari langkah-langkahnya yaitu mulai dari pertama menyajikan informasi, kedua think, ketiga pair, keempat share, kelima evaluasi, dan

\section{p-ISSN 2407-4934 \\ e-ISSN 2355-1747}


keenam penghargaan. Langkah kegiatan yang telah digunakan merupakan kegiatan pembelajaran yang melibatkan siswa secara langsung dan menuntut siswa untuk berpikir secara ilmiah yaitu secara logis dan empiris berdasarkan data-data atau informasi yang diamati oleh siswa.

Penggunaan pendekatan scientific dapat mengubah pola pikir siswa yang dari hafalan menjadi logis dan empiris. Siswa akan lebih kritis, kreatif dan bukan hanya hafalan tetapi akan lebih ke arah pembuktian berdasarkan faktafakta yang ada. Dari langkah-langkah yang digunakan di dapat juga peningkatan hasil belajar dapat ditinjau dari besarnya skor maksimum, skor minimum dan skor rata-rata, yang ditunjukkan melalui berikut:

\begin{tabular}{lccc}
\hline Kriteria & $\begin{array}{c}\text { Pra } \\
\text { Siklus }\end{array}$ & $\begin{array}{c}\text { Siklus } \\
\text { I }\end{array}$ & $\begin{array}{c}\text { Siklus } \\
\text { II }\end{array}$ \\
\hline $\begin{array}{l}\text { Nilai } \\
\text { Maksimum }\end{array}$ & 75 & 83 & 95 \\
$\begin{array}{l}\text { Nilai } \\
\text { Minimum } \\
\text { Rata-rata }\end{array}$ & 40 & 65 & 79 \\
\hline
\end{tabular}

Tabel 2. Distribusi Frekuensi Hasil Belajar Siswa berdasarkan Nilai Ratarata, Nilai Maksimum, dan Nilai Minimum Pra Siklus, Siklus I, \& Siklus II

Dari tabel di atas, nampak peningkatan hasil belajar. Peningkatan hasil belajar tersebut, nampak dari peningkatan besarnya skor maksimum, skor minimum dan skor rata-rata dari pra siklus, siklus I dan siklus II. Pada pra siklus besarnya skor maksimum yang dicapai siswa adalah 75 , skor minimum 40 dan skor rata-rata 62 . Pada siklus I perolehan skor maksimum meningkat menjadi 83 , skor minimum meningkat menjadi 65 dan skor ratarata meningkat menjdai 76. Selanjutnya pada akhir siklus II skor maksimum mencapai 95, skor minimum mencapai 79 dan skor rata-rata mencapai 85 .

Berdasarkan uraian pembahasan hasil penelitian diatas, terbukti bahwa tindakan penelitian yang berupa pendekatan scientific dengan model think pair share dapat meningkatkan hasil belajar siswa berdasarkan ketuntasan pada siklus II sebesar $100 \%$ dari 19 siswa. Hal ini sejalan dengan pendekatan saintifik merupakan sebuah pendekatan pembelajaran yang menekankan pada aktifitas siswa melalui kegiatan mengamati, menanya, menalar, mencoba, dan membuat jejaring pada kegiatan pembelajaran di sekolah (Rusman: 2017: 422). Setelah siswa dilibatkan langsung dalam pembelajaran hasil belajar meningkat seperti yang telah didapatkan di siklus I hasil belajar berdasarkan ketuntasan mencapai $63 \%$ dari keluruhan siswa, meningkat lagi di siklus II hasil belajar berdasarkan ketuntasan siswa sebesar $100 \%$. Hasil belajar berdasarkan skor rata-rata siswa pada siklus I sebesar 76 dan pencapaian hasil belajar berdasarkan skor rata-rata siswa pada siklus II juga meningkat yaitu sebesar 85. Hal ini membuktikan bahwa tindakan penelitian berupa pendekatan 
scientific dengan model think pair share dapat meningkatkan hasil belajar siswa.

\section{SIMPULAN}

Berdasarkan hasil penelitian dan pembahasan disimpulkan bahwa peningkatan hasil belajar dapat diupayakan melalui pendekatan scientific dengan model think pair share pada kelas IV SDN Blotongan 01, terbukti. Hal ini ditunjukkan dengan adanya peningkatan hasil belajar berdasarkan ketuntasan pada pra siklus, siklus I dan siklus II yaitu 42\%; 63\%; dan $100 \%$. Peningkatan hasil belajar berdasarkan skor maksimum berturutturut dari pra siklus, siklus I dan siklus II sebesar 75; 83; dan 95. Peningkatan hasil belajar berdasarkan skor minimum berturut-turut dari pra siklus, siklus I dan siklus II sebesar 40; 65; dan 79. Peningkatan hasil belajar berdasarkan skor rata-rata berturut-turut dari pra siklus, siklus I dan siklus II sebesar 62; 76; dan 85. Keberhasilan penelitian ini ditunjukkan oleh pencapaian ketuntasan hasil belajar siswa (dengan KKM 75) mencapai $100 \%$ dari seluruh siswa.

\section{DAFTAR RUJUKAN}

Hajar, Ibnu. 2013. Panduan Lengkap Kurikulum Tematik untuk SD/MI. Jogjakarta: DIVA Press.

Marjan, Johari, Arnyana, Putu, dan Setiawan, Nyoman. 2014. Pengaruh pembelajaran Pendekatan Saintifik Terhadap
Hasil Belajar Biologi dan Keterampilan Proses Sains Siswa MA Mu'allimat NW Pancor Selong kabupaten lombok Timur Nusa Tenggara Barat. Vol 4. Singaraja: Undiksha.

Peraturan menteri Pendidikan dan Kebudayaan Republik Indonesia Nomor 23 Tahun 2016 tentang Standar Penilaian Pendidikan. 2016. Jakarta: Menteri Pendidikan dan Kebudayaan RI.

Rusman. 2017. Belajar dan Pembelajaran Berorientasi Standar Proses Pendidikan. Jakarta: Kencana.

Undang-Undang Republik Indonesia Nomor 20 Tahun 2003 tentang Sistem Pendidikan Nasional. 2003. Jakarta: Sekretaris Negara RI.

Winantara dan Jayanta. 2017. Penerapan Model Pembelajaran TPS Untuk meningkatkan Hasil Belajar IPA Siswa Kelas V SD No 1 Mengwitani. Vol 1(1) pp. 9-19. Singaraja: Undiksha

\section{p-ISSN 2407-4934 \\ e-ISSN 2355-1747}

